\title{
Embedded elements in the IncP $\beta$ plasmids R772 and R906 can be mobilized and can serve as a source of diverse and novel elements
}

\author{
Steve Petrovskit and Vilma A. Stanisich \\ Department of Microbiology, La Trobe University, Victoria 3086, Australia
}

Correspondence

Vilma A. Stanisich

v.stanisich@latrobe.edu.au

Received 20 December 2010

Revised 10 February 2011

Accepted 6 March 2011

\begin{abstract}
IncP plasmids are important contributors to bacterial adaptation. Their phenotypic diversity is due largely to accessory regions located in one or two specific parts of the plasmid. The accessory regions are themselves diverse, as judged from sequenced plasmids mostly isolated from nonclinical sources. To further understand the diversity, evolutionary history and functional attributes of the accessory regions, we compared R906 and R772, focusing on the oriV-trfA accessory region. These IncP $\beta$ plasmids were from porcine and clinical sources, respectively. We found that the accessory regions formed potentially mobile elements, Tn510 (from R906) and Tn511 (from R772), that differed internally but had identical borders. Both elements appeared to have evolved from a TnAO22-like mer transposon that had inserted into an ancestral IncP $\beta$ plasmid and then accrued additional transposable elements and genes from various proteobacteria. Structural comparisons suggested that Tn510 (and a descendent in pB10), Tn511 and the mer element in pJP4 represent three lineages that evolved from the same widely dispersed IncP $\beta$ carrier. Functional studies on Tn511 revealed that its mer module is inactive due to a merT mutation, and that its aphA/ region is prone to deletion. More significantly, we showed that by providing a suitable transposase gene in trans, the defective Tn510 and Tn511 could transpose intact or in part, and could also generate new elements (stable cointegrates and novel transposons). The ingredients for assisted transposition events similar to those observed here occur in natural microcosms, providing non-self-mobile elements with avenues for dispersal to new replicons and for structural diversification. This work provides an experimental demonstration of how the complex embedded elements uncovered in IncP plasmids and in other plasmid families may have been generated.
\end{abstract}

\section{INTRODUCTION}

Plasmids of the broad-host-range incompatibility group $\mathrm{P}$ (also denoted IncP-1) were first detected in Pseudomonas aeruginosa and enteric bacteria from clinical sources (Thomas \& Smith, 1987). They are considered to be potent mediators of horizontal gene transfer, since they promote both inter- and intra-species conjugation and can replicate in taxonomically disparate proteobacteria (Adamczyk \& Jagura-Burdzy, 2003; Krishnapillai, 1988; Thomas, 2000). Until the last decade, significant sequence data were available only for plasmids RP1/RK2 (the socalled 'Birmingham' plasmids) (Pansegrau et al., 1994) and R751 (Thorsted et al., 1998), which, respectively, serve as

tPresent address: Biotechnology Research Centre, La Trobe University, PO Box 199, Victoria 3552, Australia.

Abbreviations: DR, direct repeat; IR, inverted repeat; TE, transposable element.

The GenBank/EMBL/DDBJ accession numbers for the Tn510 and Tn511 sequences of R906 and R772 are DQ471307 and EU287476, respectively. the prototype plasmids of the $\operatorname{IncP} \alpha$ and $\operatorname{Inc} P \beta$ subgroups. Currently, 10 or more $\operatorname{IncP} \beta$ plasmids have been fully sequenced as have several representatives of four other IncP subgroups (Bahl et al., 2009; Schlüter et al., 2007; Sen et al., 2010). Each subgroup contains phylogenetically distinguishable plasmid lineages (Bahl et al., 2009; Kamachi et al., 2006). The newer collection of IncP plasmids, in contrast to the early one (Smith \& Thomas, 1989), has been drawn mainly from non-clinical sources (e.g. water, activated sludge and soil) and from diverse hosts, some unknown (Bahl et al., 2009; Schlüter et al., 2007). The ubiquitous distribution of the IncP plasmids underscores their importance in horizontal gene transfer and has led to efforts to define and better understand plasmid population dynamics and factors that affect them (De Gelder et al., 2005, 2007).

Almost all of the IncP plasmids studied encode traits such as resistance to various antibiotics and antimicrobials, and degradation of complex compounds and xenobiotics, many of which are clinically and environmentally relevant (Bahl et al., 2009; Schlüter et al., 2007). In some instances, the 
traits are encoded by class I or class II transposons that are demonstrably self-mobile (Schlüter et al., 2007; Villarroel et al., 1983). Such modular elements represent acquired accessory genes that have persisted on the plasmid because of a selective advantage to the bacterial host. Knowledge of the plasmid DNA sequences has been crucial in revealing the true nature and complex organization of the accessory genes, which include combinations of functional modular elements as well as defective and degraded structures and incidental (orphan) genes. In some instances, the entire accessory unit is phenotypically cryptic (Schlüter et al., 2007).

The accessory genes are typically confined to two regions of the plasmid (Trefault et al., 2004; Villarroel et al., 1983), thereby interrupting a conserved plasmid 'backbone' that was postulated to be contiguous in the IncP plasmid progenitor (Smith \& Thomas, 1987, 1989; Smith et al., 1993) and is recognizable as such in some extant members [e.g. pBP136 (Kamachi et al., 2006) and pJP4 (Trefault et al., 2004)]. The two regions are situated between the replicative functions, oriV and $\operatorname{trf} A$, and the conjugation functions, $\operatorname{tra}(\operatorname{Tra} 1)$ and $\operatorname{trb}$ (Tra 2). The accessory genes that occur in the two regions are not necessarily located at the same site in the backbone, so that plasmids can be distinguished phylogenetically based on the position and type of insert that is present (Kamachi et al., 2006; Sota et al., 2007). Of relevance to this study are the $\operatorname{IncP} \beta$ plasmids pB10 (Schlüter et al., 2003), pJP4 (Trefault et al., 2004), R772 (Coetzee, 1978) and R906 (Terakado \& Mitsuhashi, 1974). The first two of these have been fully sequenced, and molecular maps, supported by limited sequence data, are available for R772 $(\sim 61 \mathrm{~kb})$ and R906 ( $58 \mathrm{~kb})$ (Smith \& Thomas, 1987, 1989; Smith et al., 1993).

Thorsted et al. (1998) suggested that accessory genes may target the oriV-trfA and tra-trb regions because each region contains an array of conserved $20 \mathrm{bp}$ inverted repeats (IRs) proposed to facilitate insertion of DNA segments. Although attractive, no experimental evidence to support this view was obtained in a study on the targeting of $\mathrm{Tn} 21 \mathrm{Km}$ to the oriV-trfA region of pBP136 (Sota et al., 2007). Instead, plasmid fitness of the insertion derivatives appeared to be a predominant factor. This finding accorded with the preponderance of Tn21-like elements found naturally in the oriV-trfA region of IncP plasmids generally (Schlüter et al., 2007) and with the observed conservation of the plasmid backbone. A different contributing factor accounts for the predominant insertion of Tn5053/Tn 402-like elements in the tra-trb region (Schlüter et al., 2007). This interaction stems from the transpositional dependence of these elements on a target-encoded resolvase (ParA) that assists oriented and directed insertion into the cognate res (resolution) sequence located in the tra-trb region (Kamali-Moghaddam \& Sundström, 2000; Minakhina et al., 1999; Petrovski \& Stanisich, 2010).

The main focus of this study is $\operatorname{R772}(\operatorname{IncP} \beta)$, obtained from a clinical Proteus mirabilis strain isolated in the USA in 1974 (Coetzee, 1978). The molecular map of R772 (Hille et al., 1983; Smith \& Thomas, 1987) indicates that its accessory genes occur in the oriV-trfA and tra-trb regions and are distinctive. Those in the oriV-trfA region are responsible for the sole (kanamycin)-resistance phenotype of R772 (Hille et al., 1983), and also include a suspected cryptic Tn501-like mercury(II)(mer)-resistance determinant (Smith \& Thomas, 1987). The position and sequence of the mer-associated IR of the cryptic element have been determined (Smith et al., 1993) and are identical to those of an intact Tn501-like element in pB10 and pJP4, suggesting that all three plasmids are derived from the same ancestral plasmid (Schlüter et al., 2003). R906 is apparently also a member of this group that is similar to pB10, based on comparative restriction-enzyme profiling (Smith \& Thomas, 1987; Schlüter et al., 2003). Its accessory genes also occur in the oriV-trfA and tra-trb regions and are responsible for the multiresistance phenotype of R906. This plasmid was isolated in Japan during 1969-1972 from a porcine Bordetella bronchiseptica strain (Hedges et al., 1974; Terakado \& Mitsuhashi, 1974).

Here, we report the sequence and functional attributes of the accessory genes in the oriV-trfA regions of R772 and R906. Our aim was to determine the diversity and evolutionary history of the genes and their propensity for lateral transfer. Our findings support the view (Schlüter et al., 2003, 2007) that the oriV-trfA accessory region is a mosaic of transposable elements (TEs), and that the regions in R772, R906, pJP4 and pB10 are phylogenetically related. We also observed, as have others (Schlüter et al., 2007), that the earlier accrued elements may lack mobility functions due to deletion mutations. Few studies have systematically assessed the ability of the in situ accessory unit, and its parts, to relocate. Our findings demonstrate that relocation is possible and that the R772 unit is especially dynamic. Since accessory genes occur in other families of plasmids and are components of bacterial genomes (e.g. Kung et al., 2010), our observations have broader applicability.

\section{METHODS}

Strains, plasmids and media. The auxotrophic Escherichia coli $\mathrm{K}-12$ derivatives used were DH5 $\alpha$ (recA1 Res ${ }^{-} \mathrm{Mod}^{+} \mathrm{Nal}^{\mathrm{R}}$ ) (Hanahan, 1983), LT101 (recA13 Res ${ }^{-}$Mod $^{-}$Rif $^{\mathrm{R}}$ ) (Palombo et al., 1989), UB281 ( $\mathrm{Rec}^{+} \mathrm{Nal}^{\mathrm{R}}$ ) (Hedges et al., 1973) and its recombination-deficient derivative UB5201 (Sanchez et al., 1982). The plasmids used are listed in Table 1. R772-1 has a mutation in $\operatorname{tnp} A$ of $\operatorname{Tn} 5403$ $\left(\operatorname{tnp} A_{5403}\right)$ that was created by BamHI cleavage of the purified plasmid, treatment with T4 DNA polymerase and religation. The introduced frameshift mutation is at nucleotide 2570 of $\operatorname{tnp} A_{5403}$. Additional plasmids that were generated in vivo are described in the text and in Table 4 (i.e. pBR322 with inserts of $\operatorname{Tn} 510, \operatorname{Tn} 511$, Tn511-2, Tn511-3 or Tn5403). Bacterial strains were grown at $37{ }^{\circ} \mathrm{C}$ in nutrient agar (NA) and nutrient broth (NB), as described previously (Palombo et al., 1989). NA was supplemented with the required antimicrobial agents at the following concentrations ( $\left.\mu \mathrm{g} \mathrm{ml}^{-1}\right)$ : oxacillin (Oxa) 200; chloramphenicol $(\mathrm{Cm})$, gentamicin sulphate $(\mathrm{Gm})$, kanamycin sulphate $(\mathrm{Km})$, mercuric chloride $(\mathrm{Hg})$ and tetracycline hydrochloride (Tc) 10; ampicillin (Ap) and rifampicin (Rif) 100; nalidixic acid (Nal) 8; streptomycin sulphate (Sm) 5. 
Determination of $\mathbf{H g}$ "-susceptibility. The sensitivity of strains was tested by agar diffusion assay. The surface of an NA plate was floodinoculated with an overnight NB culture of the strain adjusted to $10^{8}$ c.f.u. $\mathrm{ml}^{-1}$. A sterile $12.7 \mathrm{~mm}$ paper disk (Schleicher \& Schuell, Antibiotica-testblattchen) was placed at the centre of the dry surface and $50 \mu \mathrm{l} 10 \mathrm{mM} \mathrm{HgCl}_{2}$ added to the disk. The diameter of the zone of inhibition was measured after incubation for $18 \mathrm{~h}$.

Conjugation procedures, transposition assay and analysis of transconjugants. Exponential-phase cultures in NB were employed in conjugation experiments performed by the quantitative filter method (Palombo et al., 1989). The donor strains (derivatives of $\mathrm{DH} 5 \alpha$ ) contained three plasmids that were sequentially introduced by transformation (for non-conjugative plasmids) or conjugation (for self-transferable plasmids), as described previously (Petrovski \& Stanisich, 2010). LT101 ( $\left.\mathrm{Rif}^{\mathrm{R}}\right)$ served as the recipient. The transposition assay involved the formation of cointegrates between the conjugative plasmid [i.e. R772, R772-1 (both $\mathrm{Km}^{\mathrm{R}}$ ) or R906 $\left(\mathrm{Hg}^{\mathrm{R}}\right)$ ] and the target plasmid, pBR322 $\left(\mathrm{Tc}^{\mathrm{R}} \mathrm{Ap}^{\mathrm{R}}\right)$, in the presence of a third plasmid $\left(\mathrm{Cm}^{\mathrm{R}}\right)$ carrying a functional or non-functional transposase $\left(t n p A_{21}\right)$ gene. Since pBR322 is non-conjugative and non-mobilizable (it lacks mob genes), the transconjugants that are recovered on Tcselective agar medium have inherited transpositional cointegrates. Consequently, they display the resistance profile of the two component plasmids except in instances where transposition involved the pBR322 amp gene. Resolution of cointegrates in the recipient was detected by recovering the pBR322 component (i.e. pBR322:: Tn or pBR322amp:: Tn). This was done by extracting DNA from $T c^{\mathrm{R}} A p^{\mathrm{R}}$ or $\mathrm{Tc}^{\mathrm{R}} \mathrm{Ap}^{\mathrm{S}}$ transconjugants and transforming it into E. coli $\mathrm{DH} 5 \alpha$ via $\mathrm{Tc}^{\mathrm{R}}$ selection. The resistance profile of the transformants indicated that all had inherited the resolved pBR322 component and not an unresolved cointegrate. In the case of pBR322amp:: Tn plasmids, the insertion site and orientation of the transposon within amp were determined in sequencing reactions using primers SP1 (5'-CTATCTCAGCGATCTGTC-3'), SP2 (5'-CGCATACACTATTCTCAG-3') and SP3 $(5$ '-TGTATCCGCTCATGAGAC- 3 '). The term ' $\alpha$-orientation' refers to transposon insertions in which the maps of pBR322 and the transposon are similarly oriented; ' $\beta$-orientation' refers to insertion in the opposite orientation. The stable cointegrate pVS1650 was formed during transposition of Tn510 from R906 to pBR322 (Table 4) and contains one complete copy of $\operatorname{Tn} 510$ and also a Tn510 remnant. The structure of pVS1650 was determined from the SstII restriction profile and from analysis of the DNA sequences at each Tn510 junction in pVS1670 (Fig. 3). The sequence data were obtained using primers SP1 and SP3, and showed that Tn510 was inserted at nucleotide 3319 of the pBR322 amp gene and was flanked by $5 \mathrm{bp}$ direct repeats (DRs) (AGATA). It also showed that one copy of Tn510 in pVS1650 had sustained an extensive deletion (from nucleotide 194 in ' tnpA1 to IRm1; Figs 1 and 3), thereby abolishing the TnpR-res resolution system.

DNA techniques and sequence determination. DNA manipulations and cloning were performed using standard methods (Sambrook et al., 1989). The DNA sequences of Tn 510 and Tn 511 were determined using suitable overlapping fragments that were cloned directly from R906 and R772 into pBluescript KS +. The fragments were sequenced at the Aggenomics Sequencing Facility (Plant Biotechnology, La Trobe University, Australia) on an Applied Biosystems ABI373 DNA analyser. The DNA extension products were generated by cycle sequencing reactions employing AmpliTaq DNA polymerase and pUC/M13 forward and reverse primers (Sambrook et al., 1989). The sequence data were compiled and analysed using the suites of programs provided by National Center for Biotechnology Information (NCBI; National Library of Medicine, Bethesda, MD USA) and ExPasy (Swiss Institute of Bioinformatics, Geneva). PCR amplification of DNA (Petrovski \& Stanisich, 2010) employed primers SP9 (5'-GAATTCGCTTATCGAGCAACTCCAT-3') and SP10 (5'-GGATCCGAATTTAATCGCGGCCTCG-3') to amplify $s o c D_{772}$, and SP32 (5'-GCGTCGACATACTTGAGAGCGGATCAG-3') and SP33 (5'-GCGTCGACGTATCAAAGCAAGATCCTG-3') to detect $\operatorname{Tn} 511-4\left(\mathrm{Km}^{\mathrm{S}}\right)$ mutants of R772.

RNA extraction and RT-PCR. Exponential-phase cultures were grown in $10 \mathrm{ml} \mathrm{NB}$ to $\mathrm{OD}_{600} \sim 0.3$, mixed with $500 \mu \mathrm{l}$ phenol: chloroform $(5: 95)$ and the cells were pelleted and resuspended in $500 \mu \mathrm{l}$ icecold buffer [10 $\mathrm{mM} \mathrm{KCl,} 5 \mathrm{mM} \mathrm{MgCl}_{2}, 10 \mathrm{mM}$ Tris/ $\mathrm{HCl}$ (pH 7.5)]. An equal volume of hot phenol \{one part phenol and five parts buffer [0.4 M NaCl, $40 \mathrm{mM}$ EDTA, $1 \%$ (v/v) $\beta$-mercaptoethanol, $1 \%(\mathrm{w} / \mathrm{v})$ SDS, $20 \mathrm{mM}$ Tris/HCl, pH 7.5]\} was added and the total incubated at $95{ }^{\circ} \mathrm{C}$ for $1 \mathrm{~min}$ to lyse the cells. After centrifugation, nucleic acids in the supernatant were extracted with $300 \mu$ phenol: chloroform $(1: 1)$

Table 1. Plasmids used in this study

\begin{tabular}{|c|c|c|}
\hline Plasmid & Relevant characteristics & Reference or source \\
\hline R772 & IncP $\beta$ conjugative plasmid; $\operatorname{Tn} 511^{+} \mathrm{Km}^{\mathrm{R}}$ & Coetzee (1978) \\
\hline R772-1 & R772 with $\operatorname{tnp} A_{5403}$ mutation in $\operatorname{Tn} 511$ & This study \\
\hline R906 & IncP $\beta$ conjugative plasmid; $\operatorname{Tn} 510^{+} \mathrm{Hg}^{\mathrm{R}} \mathrm{Oxa}^{\mathrm{R}} \mathrm{Sm}^{\mathrm{R}} \mathrm{Su}^{\mathrm{R}}$ & Hedges et al. (1974) \\
\hline pBBR1MCS-5 & Broad-host-range vector; $\mathrm{Gm}^{\mathrm{R}}$ & Kovach et al. (1995) \\
\hline pBR322 & E. coli vector; $\mathrm{Ap}^{\mathrm{R}} \mathrm{Tc}^{\mathrm{R}}$ & Bolivar et al. (1977) \\
\hline pBluescript KS + & E. coli vector; $\mathrm{Ap}^{\mathrm{R}}$ & Stratagene \\
\hline pUB307 & IncP $\alpha$ conjugative plasmid $\left(\mathrm{Tc}^{\mathrm{R}} \mathrm{Km}^{\mathrm{R}}\right)$ & Bennett et al. (1977) \\
\hline pUB2401 & pACYC184tet $:: \operatorname{Tn} 21$; the plasmid $\left(\mathrm{Cm}^{\mathrm{R}}\right)$ carries $\operatorname{Tn} 21\left(\mathrm{Hg}^{\mathrm{R}} \mathrm{Su}^{\mathrm{R}} \mathrm{Sm}^{\mathrm{R}}\right)$ & de la Cruz \& Grinsted (1982) \\
\hline pVS1650 & $\begin{array}{l}\text { Stable R906-pBR322 cointegrate; carries } \mathrm{Tn} 510 \text { and a Tn510 remnant; } \\
\mathrm{Hg}^{\mathrm{R}} \mathrm{Oxa}^{\mathrm{R}} \mathrm{Sm}^{\mathrm{R}} \mathrm{Su}^{\mathrm{R}} \mathrm{Tc}^{\mathrm{R}} \mathrm{Ap}^{\mathrm{S}}\end{array}$ & This study \\
\hline pVS1659 & pBluescript KS + with R906 EcoRI-HindIII clone encoding merTP ${ }_{510} ; \mathrm{Ap}^{\mathrm{R}}$ & This study \\
\hline pVS1660 & BamHI deletant of pUB2401; lacks most of $\mathrm{Tn} 21$ but retains $\operatorname{tn} p A_{21} ; \mathrm{Cm}^{\mathrm{R}}$ & This study \\
\hline pVS1661 & SphI-EcoRV deletant of pVS1660; lacks all of Tn $21 ; \mathrm{Cm}^{\mathrm{R}}$ & This study \\
\hline pVS1670 & $\begin{array}{l}\text { SstII-ligation derivative of pVS1650; contains pBR322 and flanking Tn510 sequences; } \\
\text { lacks most of R906; } \mathrm{Tc}^{\mathrm{R}}\end{array}$ & This study \\
\hline pVS1683 & pBluescript KS + with R772 EcoRI-HindIII clone encoding merTP ${ }_{511} ; \mathrm{Ap}^{\mathrm{R}}$ & This study \\
\hline pVS1692 & pBBRMCS-5 with R906 EcoRI-HindIII clone encoding merTP ${ }_{510} ; \mathrm{Gm}^{\mathrm{R}}$ & This study \\
\hline pVS1719 & pBR322:: Tn511; $\mathrm{Tc}^{\mathrm{R}} \mathrm{Km}^{\mathrm{R}}$ & This study \\
\hline
\end{tabular}


then twice with chloroform alone, and precipitated, on ice, with 2propanol. After centrifugation for $15 \mathrm{~min}$ at 13000 r.p.m. $(17000 \mathrm{~g}$ ), the nucleic acid pellet was washed with $70 \%$ ethanol, dried and dissolved in $30 \mu \mathrm{l}$ diethyl-pyrocarbonate-treated single-distilled $\mathrm{H}_{2} \mathrm{O}$ (DEPC-sdH $\mathrm{H}_{2} \mathrm{O}$ ) and treated with $1 \mathrm{U}$ DNase I (Promega). The RNA was extracted and precipitated, as described above, resuspended in DEPC$\mathrm{sdH}_{2} \mathrm{O}$ and quantified spectrophotometrically. RT-PCR was performed in two steps. Reverse transcription was performed using $2 \mu \mathrm{g}$ template RNA annealed to primer SP8 (5'-CGTAAGCATCTCGCCAAG- $3^{\prime}$ ) in a reaction mixture containing $200 \mathrm{U}$ Moloney murine leukaemia virus reverse transcriptase (Promega), the supplied reaction buffer, $1.25 \mathrm{mM}$ of each dNTP and $25 \mathrm{U}$ rRNasin RNase inhibitor (Promega), in a total reaction volume of $15 \mu \mathrm{l}$. After incubation at $42{ }^{\circ} \mathrm{C}$ for $1 \mathrm{~h}$, the reaction was terminated by heating $\left(95^{\circ} \mathrm{C}\right.$ for $5 \mathrm{~min}$ ) and the reversetranscription products were subjected to PCR amplification using Taq DNA polymerase (Petrovski \& Stanisich, 2010) and primers SP8 and SP13 (5'-GTCTGACAAAACCGTAGC-3').

Nucleotide sequence accession numbers. The accession numbers of sequences used in this study are J01749 (pBR322), Z00027 (Tn501) and AF071413 (Tn21), together with others listed in Table 2.

\section{RESULTS AND DISCUSSION}

\section{The oriV-trfA regions of $\mathrm{R772}$ and $\mathrm{R} 906$ contain defective derivatives of the same mer transposon}

We determined the DNA sequences of R906 and R772 from a PstI site near oriV to a position about $260 \mathrm{bp}$ beyond a HindIII site near trfA (Fig. 1). On analysis, each sequence revealed the presence of a defective, nested transposon embedded within plasmid sequences. The transposon in R906 was named $\operatorname{Tn} 510$ (13 $336 \mathrm{bp}$ ); that in R772 was named Tn511 (18769 bp). Both transposons were clearly related, since their respective $38 \mathrm{bp}$ IR termini (IRt1 and IRm1) are identical and differ only in a few bases from those of Tn21 (Liebert et al., 1999) (Fig. 2a). The $5 \mathrm{bp}$ DR sequences that flank Tn510 and Tn511 were also identical (i.e. TGCCT), and are each part of longer sequences recognizable as $\operatorname{IncP} \beta$ backbone (i.e. the $40 \mathrm{bp}$ from the PstI site to IRt1 and the $262 \mathrm{bp}$ beyond IRm1) (Fig. 1). A simple explanation of these features is that Tn510 and Tn511, although different in size, are both derived from a progenitor transposon that entered a common ancestor of R906 and R772 by transpositional insertion. From the parts of the $\mathrm{Hg}^{\mathrm{II}}$-resistance (mer) and transposition ( $t n p)$ modules that have been retained, the progenitor is most like the Tn21/Tn501-family transposon TnAO22 (Ng et al., 2009) (Fig. 2b, c), and will be ascribed this name to aid discussion.

Specifically, the type 6 mer modules (merRTPADEorf2) of Tn510 and Tn511 are of identical length and sequence (>99\%) to those of TnAO22 and Tn501 (Liebert et al., 1997) (Table 2). The tnp modules are incomplete. They too are near identical to tnp of $\operatorname{Tn} A O 22$, and more similar to

Table 2. Features and coding sequences of $\operatorname{Tn} 510$ and $\operatorname{Tn} 511$, and their closest relatives

\begin{tabular}{|c|c|c|c|c|}
\hline \multirow{2}{*}{$\begin{array}{l}\text { Feature and/or } \\
\text { gene sequence }\end{array}$} & \multicolumn{2}{|c|}{ Tn coordinates (nucleotides) $\dagger$} & \multirow{2}{*}{$\begin{array}{l}\text { Percentage nucleotide identity to the } \\
\text { most closely related sequences } \ddagger\end{array}$} & \multirow{2}{*}{$\begin{array}{c}\text { GenBank accession } \\
\text { numbers }\end{array}$} \\
\hline & $\operatorname{Tn} 510$ & $\operatorname{Tn} 511$ & & \\
\hline IS 1071 & $274-3477$ & $\mathrm{NA}$ & $\begin{array}{l}100 \% \text { to pJP4 from Ralstonia eutropha and } \\
\text { pTSA from Comamonas testosteroni }\end{array}$ & AF311437; CP000541 \\
\hline IRt2-' $\operatorname{tnp} A 2$ & $\mathrm{NA}$ & $639-3420$ & $\begin{array}{l}99 \% \text { to pMOL } 28 \text { from C. metallidurans and } \\
\text { a fosmid clone from an unknown organismll }\end{array}$ & AB266144; AJ877225 \\
\hline$' \operatorname{Tn} 5393 c$ & $3478-7836$ & $\mathrm{NA}$ & $\begin{array}{l}99 \% \text { to pRAS2 from Aeromonas salmonicida and } \\
\text { pPSR1 from Pseudomonas syringae }\end{array}$ & AF262622; AY342395 \\
\hline $\operatorname{Tn} 5403$ & $\mathrm{NA}$ & $3421-7083$ & $99 \%$ to Klebsiella pneumoniae and pEC_L46 from E. coli & X75779; GU371929 \\
\hline IRt3-tnpA3*R & $\mathrm{NA}$ & $10562-14252$ & $\begin{array}{l}99 \% \text { to pMOL } 28 \text { from C. metallidurans and } \\
\text { a fosmid clone from an unknown organismll }\end{array}$ & AB266144; AJ877225 \\
\hline $\begin{array}{l}\operatorname{tnpA1R-orf2-} \\
\text { mer-IRm1 }\end{array}$ & $7837-13346$ & $14253-18769$ & $\begin{array}{l}99 \% \text { to pAO22 from Achromobacter sp. and } \\
\text { pMOL } 28 \text { from C. metallidurans }\end{array}$ & EU696790; X90708 \\
\hline
\end{tabular}

$\nmid$ The sequences of Tn510 and Tn511 are available under GenBank accession numbers DQ471307 and EU287476, respectively. NA, Not applicable. $\$$ The sequence of Tn510 is identical to the corresponding parts of a Tn510 derivative in pB10 (accession number AJ564903).

$\$ A^{\prime}$ symbol indicates the part of the gene (or feature) that is missing (i.e. the $3^{\prime}$ end and/or the $5^{\prime}$ end).

IIThese sequences are the best of only several database entries with high identity. All other sequences listed in Table 2 had high identity to numerous database entries for different plasmids and/or bacteria. 

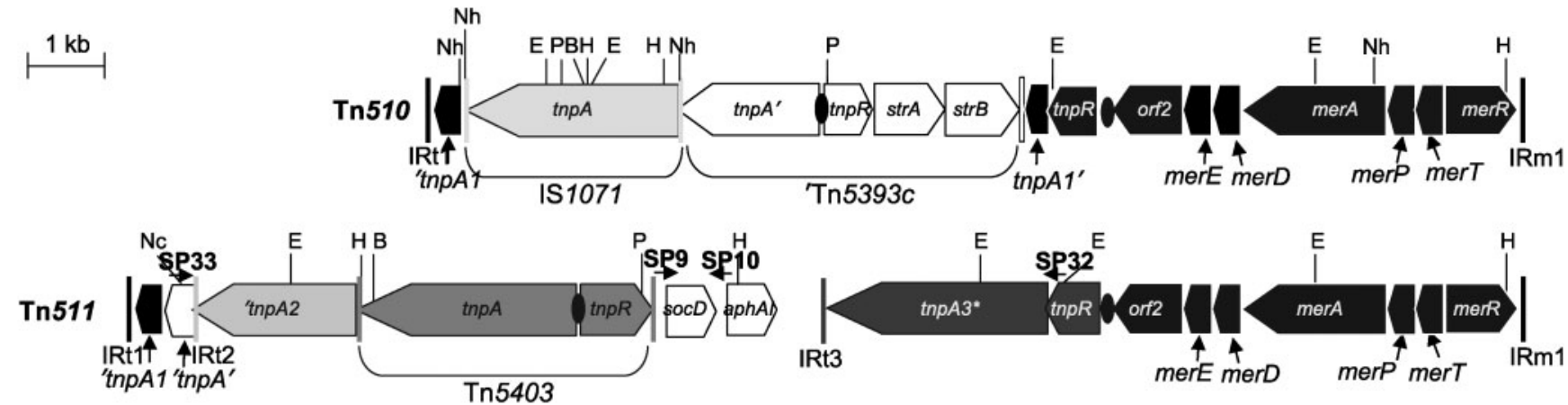

Tn511-2

Tn511-3

Tn511-4 - - - -

Fig. 1. Comparison of the genetic maps and mosaic structures of $\operatorname{Tn} 510$ (13336 bp) and $\operatorname{Tn} 511$ (18 $769 \mathrm{bp})$. These related defective transposons occur at the same position in the oriV-trfA backbone region of R906 and R772, respectively, bounded by identical 5 bp DRs (TGCCT). The various genes and their direction of transcription are represented by arrows. Other details are provided in Table 2. Genes and other components that are part of the same functional module are similarly shaded, except for the tnpA-defective $\operatorname{Tn} 5393 \mathrm{c}$ and the orphan genes $\operatorname{soc} D$ and $a p h A$, which are unshaded. IRs that flank modular elements are represented by vertical lines. The Tn21-like IRs that flank mer genes (IRm) or tnp genes (IRt) are numbered to identify the different remnant elements in which they occur. Black ovals indicate the position of resolution sites (res). The bars below the map of Tn511 indicate the compositions of Tn511-2 (flanked by IRt2 and IRm1), Tn511-3 (flanked by IRt3 and IRm1) and Tn511-4. The last arose from RecA-mediated recombination between 'tnpA2 and tnpA3 at unknown sites within the region indicated by the dashed line. Black arrows with an SP number indicate the binding regions of PCR primers referred to in the text. Cleavage sites are shown for the restriction enzymes EcoRI (E), BamHI (B), Hindlll (H), Pstl (P), Ncol (Nc) and Nhel (Nh).

the module in $\operatorname{Tn} 21$ ( $\sim 97 \%$ identity) than to that in $\operatorname{Tn} 501$ ( $70 \%$ identity). Instead of the expected tnpAR-res components, Tn511 contains a $3^{\prime}$ remnant of the transposase gene (i.e. the $207 \mathrm{bp}$ 'tnpA1) adjacent to IRt1. In Tn510, the wild-type tnpA1 has been disrupted and the central portion deleted. Consequently, the $3^{\prime}$ remnant occurs near IRt1 (i.e. the $239 \mathrm{bp}$ 'tnpA1), and the $5^{\prime}$ remnant (i.e. the $\left.264 \mathrm{bp} \operatorname{tnp} A 1^{\prime}\right)$, together with the resolvase gene $(\operatorname{tnp} R)$ and res sequence, occurs near the mer module. It appears, therefore, that the $\mathrm{Tn} A O 22$ tnp module underwent significant changes during its evolution into Tn510 and Tn511 (discussed below), whereas the mer module remained largely unaffected. The latter finding was unexpected, since $\mathrm{Hg}^{\mathrm{II}}$-resistance is a trait of $\mathrm{R} 906$ but not of R772, which is suspected to carry a mer remnant (Smith \& Thomas, 1989). We investigated the basis of this phenotypic difference using E. coli K-12 as the host.

\section{R772 confers sensitivity to $\mathrm{Hg}^{\prime \prime}$ because the MerT import protein encoded by Tn511 is defective}

The mer modules of Tn510 (from R906) and Tn511 (from R772) were found to be identical, except for single-base differences in merT (351 bp), which encodes an $\mathrm{Hg}^{\mathrm{II}}$ transport protein, and merA (1686 bp), which encodes the $\mathrm{Hg}^{\mathrm{II}}$ reductase (Barkay et al., 2003). The differences in $\operatorname{merT}_{511}(\mathrm{~T} \rightarrow \mathrm{A}$ at nucleotide 32$)$ and $\operatorname{mer}_{511}(\mathrm{~A} \rightarrow \mathrm{T}$ at nucleotide 1661) result in predicted amino acid substitutions (i.e. $\quad$ Leu $^{11} \rightarrow$ Pro in $\quad$ MerT $_{511}, \quad$ Lys $^{554} \rightarrow$ Met in
MerA $\left._{511}\right)$. Either of the mutated genes could be responsible for the $\mathrm{Hg}^{\mathrm{S}}$ phenotype of $\mathrm{R} 772$, since a merA or $\operatorname{merT}$ mutation can result in $\mathrm{Hg}^{\mathrm{II}}$ sensitivity (Hamlett et al., 1992). To individually assess the functions of $m e r T_{511}$ and $m e r A_{511}$, we took advantage of the fact that a different phenotype, $\mathrm{Hg}^{\mathrm{II}}$ hypersensitivity, arises when wild-type merT is expressed in the absence of wild-type merA (whether or not merP is present) (Lund \& Brown, 1987). We therefore cloned merTP from Tn510 and Tn511 and used disk-diffusion assays to study the phenotypic effect of the genes when present alone or in strains with R906 (which has a functional $m e r A_{906}$ ) or R772 (which has a potentially dysfunctional $m_{e r} A_{772}$ ).

The data obtained (Table 3) confirm that R906, and not $\mathrm{R} 772$, confers $\mathrm{Hg}^{\mathrm{II}}$ resistance (lines 1-3). They also showed that the $\mathrm{R} 906$ merTP 510 genes cause $\mathrm{Hg}^{\mathrm{II}}$ hypersensitivity when $m_{e r} A_{906}$ is absent (line 4), and that hypersensitivity was counteracted when $m e r A_{906}$ was present. The effect was partial (line 7) when $\mathrm{Hg}^{\mathrm{II}}$ import was elevated, and complete (line 9) when import was lower (i.e. when the high- and low-copy-number pBlue-merTP $P_{510}$ and pBBGmerTP 510 plasmids were present, respectively). Significantly, the cloned R772 merTP $P_{511}$ genes failed to confer $\mathrm{Hg}^{\mathrm{II}}$ hypersensitivity (compare lines 4 and 5). Since $m e r P_{510}$ and $m e r P_{511}$ are identical, this observation provides genetic evidence that $m e r T_{511}$ is defective. In contrast, the R772 merA $A_{511}$ gene, despite a missense mutation, appears to be functional, since strains with the active MerTP $_{510}$ import system and with either merA $A_{510}$ (in R906) 
(a)

\section{$\underline{\text { IR }}$}

IRt1, IR AO22 $_{\text {. }}$ IRt2/t3, IR $\mathrm{IRm} 1, \mathrm{IR}_{\mathrm{AO} 22}$

$\mathbb{I R}_{21}$

(b)

IS1071

Tn5393c

$\operatorname{Tn} A O 22$

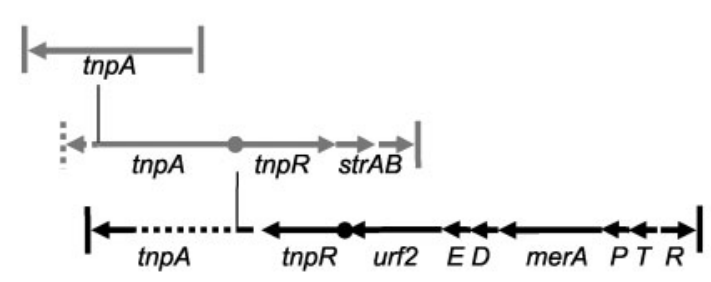

(c)

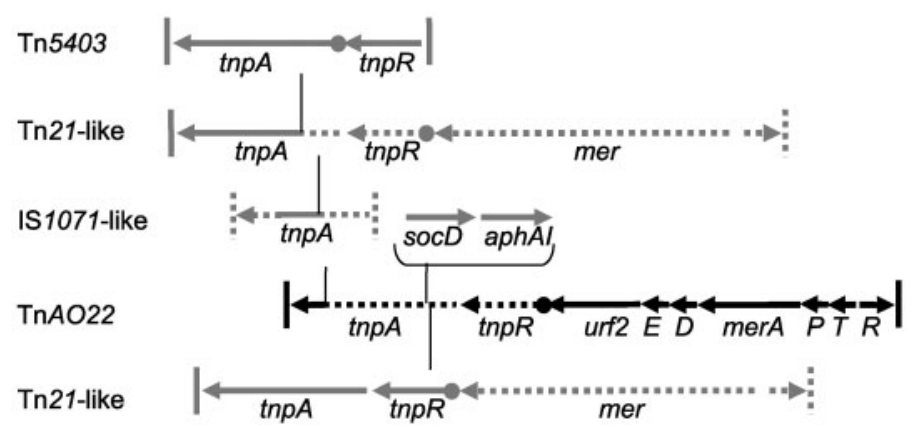

Inverted repeat $\left(5^{\prime}-3^{\prime}\right)$

GGGGTCGCCTCAGAAAACGGAAAATAAAGCACGCTAAG

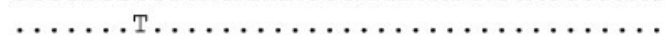

GGGGTCGTCTCAGAAAACGGAAAATAAAGCACGCTAAG

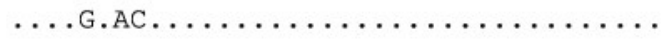

Fig. 2. Tn21-related IR sequences (a) and the proposed genesis of $\operatorname{Tn} 510$ (b) and $\operatorname{Tn} 511$ (c). The sequences of the IR termini of Tn510 and Tn511 are compared with those of Tn21, $\mathrm{Tn}$ AO22 and internal IRs in Tn511 (see Fig. 1 and text); each group of sequences is identical, except for the four nucleotides shown. $\operatorname{Tn} 510$ and $\operatorname{Tn} 511$ are each built on a $\operatorname{Tn} A O 22$ platform whose genetic map is shown in black type. Transposons have been added sequentially to form $\operatorname{Tn} 510$ and $\operatorname{Tn} 511$ (see text for details). Maps of the elements are shown above the TnAO22 map. In Tn511, the order of acquisition of $\operatorname{soc} D-a p h A 1$ and the mer transposon shown below the $\mathrm{TnAO} 22$ map is unknown. IRs are represented by vertical bars at the termini of the elements and res sequences by filled circles. Deleted sequences are indicated by dashed lines.

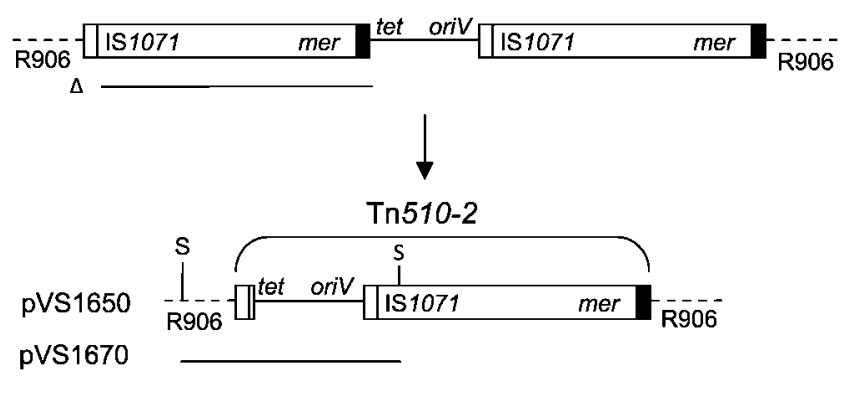

Fig. 3. Comparison of the structures of a Tn510-mediated transpositional cointegrate and the stable derivative pVS1650. The upper map depicts part of a typical R906-pBR322 transpositional intermediate. The pBR322 replicon $\left(\right.$ tet $^{+}$oriV $\left.^{+}\right)$is flanked by direct copies of $\operatorname{Tn} 510\left(\mathrm{IS} 1071^{+} \mathrm{mer}^{+}\right)$whose left and right IRs are represented by small white and black boxes, respectively. A deletion $(\Delta)$ of most of the left copy of Tn510 resulted in the formation of pVS1650, depicted in the lower map. The structure of pVS1650 was deduced from restriction enzyme profiles (not shown) and from the DNA sequences at each pBR322-Tn510 junction present in pVS1670 using primers SP1 and SP3. The left junction contains a Tn510 remnant (nucleotides $1-194$ ). The potentially mobile novel transposon that encompasses the pBR322 replicon was denoted Tn510-2. Cleavage sites for Sstll (S) are indicated. or $m e r A_{511}$ (in R772) are phenotypically similar (compare lines 7 and 10 and lines 9 and 12). Our conclusion that MerT $_{511}$ is defective is also consistent with the basal level sensitivity (i.e. a $3 \mathrm{~mm}$ zone) exhibited by the strain with $\operatorname{merTP}_{511}$ and $\operatorname{mer}_{511}$ (line 11). The changed residue in $\operatorname{MerT}_{511}\left(\right.$ Leu $^{11} \rightarrow$ Pro) is near the first putative transmembrane helix of the protein (residues 12-34) (Barkay et al., 2003). Consequently, it may alter the membrane topology or function of MerT $_{511}$, thereby affecting critical residues in the helix, such as the vicinal $\mathrm{Cys}^{24}$ and $\mathrm{Cys}^{25}$, which are required for the $\mathrm{Hg}^{\mathrm{II}}$ resistance and/or hypersensitivity phenotypes (Hobman \& Brown, 1996).

\section{Tn510 in R906 and Tn511 in R772 contain different nested components}

Although Tn510 and Tn511 are clearly derived from the same TnAO22 base element, they differ in other structural components. Tn510 contains part of Tn5393c (L'AbéeLund \& Sørum, 2000): the streptomycin-resistance (strAB) arm is present but the $3^{\prime}$ end of $t n p A_{5393}$ and the associated IRt are missing (Fig. 1). Tn510 also contains IS1071; however, this is not flanked by the $5 \mathrm{bp}$ DRs typically associated with its transposition (Sota et al., 2006). Since the sequences of the Tn510 components directly abut each other, we conclude that $\operatorname{Tn} A O 22$ first inherited $\operatorname{Tn} 5393 c$, 
Table 3. $\mathrm{Hg}^{\prime \prime}$-resistance phenotype of E. coli strains carrying cloned merTP genes from Tn510 and Tn511

\begin{tabular}{|c|c|c|c|}
\hline \multirow{2}{*}{$\begin{array}{l}\text { Line number } \\
\text { cited in text }\end{array}$} & \multicolumn{2}{|c|}{ Plasmids in $E$. coli DH5 $\alpha$} & \multirow[t]{2}{*}{ Zone diameter $\dagger(\mathrm{mm})$} \\
\hline & $\operatorname{IncP} \beta(T n)$ & Coresident plasmid ${ }^{\star}$ & \\
\hline 1 & None & None or empty vector & 4 \\
\hline 2 & R906 (Tn510) & None or empty vector & 0 \\
\hline 3 & $\mathrm{R} 772(\operatorname{Tn} 511)$ & None or empty vector & 3 \\
\hline 4 & None & pBlue-merTP $P_{510}$ & 11 \\
\hline 5 & None & pBlue-merTP $P_{511}$ & 5 \\
\hline 6 & None & pBBG-merTP 510 & 6 \\
\hline 7 & R906 (Tn510) & pBlue-merTP $P_{510}$ & 6 \\
\hline 8 & R906 (Tn510) & pBlue-merTP $P_{511}$ & 0 \\
\hline 9 & R906 (Tn510) & pBBG-merTP 510 & 0 \\
\hline 10 & R772 (Tn511) & pBlue-merTP 510 & 7 \\
\hline 11 & $\mathrm{R} 772(\operatorname{Tn} 511)$ & pBlue-merTP $P_{511}$ & 3 \\
\hline 12 & R772 (Tn511) & pBBG-merTP 510 & 0 \\
\hline
\end{tabular}

${ }^{\star}$ The empty vectors were pBlue $(=\mathrm{pBluescriptKS}+)$ and $\mathrm{pBBG}(=\mathrm{pBBR} 1 \mathrm{MCS}-5)$. Derivatives of these were pVS1659 and pVS1692 (both with merTP 510 $)$ and pVS1683 $\left(\right.$ merTP $\left._{511}\right)$.

$\dagger$ The results shown are from a single disk-diffusion assay. The data from independent assays displayed the same trends, although the diameter of zones of clearing may have differed $( \pm 1 \mathrm{~mm})$.

which then inherited IS1071 (Fig. 2b). If the respective insertions occurred towards the $5^{\prime}$ end of $\operatorname{tnp} A 1$ and the $3^{\prime}$ end of $\operatorname{tnp} A_{53930}$ a leftward IS1071-mediated deletion would account for the missing sequences (i.e. $\operatorname{tnp} A^{\prime}$ $\mathrm{IRt}_{5393 c}$, 'tnpA1' and the left DR of IS1071).

Tn 511 is structurally more complex than Tn510. In addition to the $\operatorname{Tn} A O 22$ base element, remnants of two other $\operatorname{Tn} 21$ like elements are present that differ in sequence identity. The larger remnant (IRt3-tnpA3*-tnpR) probably originated from a Tn21-like element (84-89\% identity) that inserted into $\operatorname{tnp} A 1$ of $\operatorname{Tn} A O 22$, and was followed by TnpR-mediated resolution at the heterologous res sites. Consequently, IRt3$\operatorname{tn} p A 3^{*}-\operatorname{tn} p R$ forms part of a hybrid transposon that has, as its other arm, res-mer-IRm1 (95-99\% identity to Tn21) (Fig. 1). The second Tn21-like remnant is IRt2-' $\operatorname{tnpA2}(99 \%$ identity). This remnant abuts $\operatorname{Tn} 5403$, a Tn3-related transposon (Rinkel et al., 1994a). Significantly, Tn5403 lacks its typical 5 bp DRs (Rinkel et al., 1994a), suggesting that it was responsible for deleting the remainder of tnpA2. Since $\mathrm{Tn} 5403$ is the sole intact element in Tn511, we assume that it is the most recently acquired entity.

The remaining components in Tn511 include three 'orphan' genes. One is an IS1071-like remnant gene, ' $\operatorname{mp} A$ ', that is in a similar position to the intact $\operatorname{tnp} A_{1071}$ in Tn510 but is only distantly related (69\%); a sequence identical to ' $\operatorname{npA}$ ' occurs in an IS1071-like element in pCNB1 (IncP $\beta$ ) (Ma et al., 2007). The other 'orphan' genes occur in a 3478 bp region that abuts Tn5403 on its right. The region is not related to reported sequences, except for aphAI and a socD-like gene (Table 2). The former encodes an aminoglycoside $3^{\prime}$-phosphotransferase responsible for the $\mathrm{Km}^{\mathrm{R}}$ phenotype of $\mathrm{R} 772$. The $s o c D_{511}$ product is $46 \%$ identical to an amino acid oxidase (SocD) involved in santhopine catabolism in Agrobacterium tumefaciens C58 (Baek et al., 2005) and to putative fructosyl amino acid oxidases in other soil-dwelling bacteria (Table 2). It is possible that $\operatorname{soc} D_{511}$ is functional, since its transcription from R772 in E. coli DH5 $\alpha$ was detected by RT-PCR (see Methods) (data not shown). R772 is to our knowledge the first example of an IncP plasmid to carry a socD-like gene.

A possible model that explains the structural origin of Tn511 is depicted in Fig. 2(c).

\section{The provision of $\operatorname{tnp} A_{21}$ in trans enables transposition of Tn510, Tn511 and the components Tn511-2 and Tn511-3}

Based on in silico findings we concluded that Tn510 and Tn511 are defective transposons, since they lack a complete tnpA gene (Fig. 1). They do, however, have intact tnpR-res loci (near merE) and terminal IRs. Thus, whilst appearing to be permanently embedded structures, we thought that $\operatorname{Tn} 510$ and $\operatorname{Tn} 511$ might relocate if a cognate $\operatorname{tn} p A$ gene (e.g. $\operatorname{tn} p A_{21}$ from $\operatorname{Tn} 21$ ) was provided in trans, as might smaller sections of Tn511 if its internal IRt 2 and IRt 3 sequences formed compatible termini with IRm1. The intact IS1071 and Tn5403 elements were potentially self-mobile. These various suppositions were tested in conjugation experiments designed to detect transposition of $\operatorname{Tn} 510\left(\mathrm{Hg}^{\mathrm{R}} \mathrm{Sm}^{\mathrm{R}}\right), \operatorname{Tn} 511\left(\mathrm{Km}^{\mathrm{R}}\right)$ and its components, in the presence and absence of $\operatorname{tnp} A_{21}$ [on pVS1661 $\left.\left(\mathrm{Cm}^{\mathrm{R}}\right)\right]$. The non-conjugative plasmid pBR322 
Table 4. Independent and $\mathrm{TnpA}_{21}$-assisted transposition of $\mathrm{Tn} 510, \mathrm{Tn} 511$ and their component elements to the target plasmid pBR322

\begin{tabular}{|c|c|c|c|c|}
\hline \multirow{2}{*}{$\begin{array}{l}\text { Line number } \\
\text { cited in text }\end{array}$} & \multicolumn{2}{|c|}{ Plasmids in donor ${ }^{\star}$ with target plasmid pBR322 } & \multicolumn{2}{|r|}{ Transconjugants $\dagger$} \\
\hline & IncP plasmid (Tn) & $\begin{array}{c}\text { Genotype of } \\
\text { helper plasmid }\end{array}$ & $\begin{array}{c}\text { Transposition } \\
\text { frequency }\end{array}$ & Transposition derivative (number) $\ddagger$ \\
\hline 1 & R906 (Tn510) & $\operatorname{tnp} A_{21}^{-}$ & $<5.0 \times 10^{-8}$ & - \\
\hline 2 & R906 (Tn510) & $\operatorname{tnp} A_{21}^{+}$ & $7.0 \times 10^{-6}$ & $\begin{array}{l}\text { pBR322amp: }: \operatorname{Tn} 510(3) ; \mathrm{pBR} 322 a m p- \\
\text { R906 cointegrate }(1)\end{array}$ \\
\hline 4 & R772-1 (Tn511) & $\operatorname{tnp} A_{21}^{-}$ & $<2.0 \times 10^{-7}$ & - \\
\hline 5 & R772-1 (Tn511) & $\operatorname{tnp} A_{21}^{+}$ & $8.8 \times 10^{-7}$ & $\begin{array}{l}\text { pBR322:: } \operatorname{Tn} 511-3(10) ; \\
\text { pBR322:: } \operatorname{Tn} 511-2(8) ; \\
\text { pBR322:: } \operatorname{Tn} 511(1)\end{array}$ \\
\hline
\end{tabular}

${ }^{*}$ Donors were derivatives of E. coli DH5 $\alpha$ carrying a conjugative plasmid [R906 $\left(\mathrm{Hg}^{\mathrm{R}}\right), \mathrm{R} 772\left(\mathrm{Km}^{\mathrm{R}}\right)$ or R772-1 (with a defective Tn5403 in Tn511)], together with pBR322 $\left(\mathrm{Tc}^{\mathrm{R}} \mathrm{Ap}^{\mathrm{R}}\right)$ and either a $\operatorname{tnp} A_{21}{ }^{+}$plasmid $(\mathrm{pVS1661})$ or its $\operatorname{tnp} A_{21}{ }^{-}$derivative (pVS1660) (both $\mathrm{Cm}^{\mathrm{R}}$ ). The recipient was LT101 $\left(\right.$ Rif $\left.^{\mathrm{R}}\right)$.

$\dagger$ Transconjugants were isolated on NA containing Rif and either $\mathrm{Hg}^{\mathrm{II}}$ or Km [to detect transfer of R906 and R772 (or R772-1), respectively] or Tc (to detect conductional transfer of pBR322). The transposition frequency represents the ratio of $\mathrm{Tc}^{\mathrm{R}}$ to $\mathrm{Hg}^{\mathrm{R}}$ transconjugants per R906 ${ }^{+}$donor, or $\mathrm{Tc}^{\mathrm{R}}$ to $\mathrm{Km}^{\mathrm{R}}$ transconjugants per R772 ${ }^{+}$(or R772-1 ${ }^{+}$) donor. The mean transfer frequencies of R906 and R772 (or R772-1) were $4.0 \times 10^{-1}$ and $4.2 \times 10^{-1}$, respectively. Experiments were performed at least three times using independently constructed donors.

$\ddagger$ The pBR322 transpositional derivatives present in transconjugants were isolated and characterized as described in Methods. The transconjugants studied were all randomly chosen from amongst the $\operatorname{Tc}^{\mathrm{R}} A \mathrm{p}^{\mathrm{R}}$ subgroup or $\mathrm{Tc}^{\mathrm{R}} A \mathrm{p}^{\mathrm{S}}$ subgroup.

$\left(\mathrm{Tc}^{\mathrm{R}} A \mathrm{p}^{\mathrm{R}}\right)$ served as the transpositional target. Its transfer was monitored via the incidence of $\mathrm{Tc}^{\mathrm{R}}$ transconjugants and is dependent on the formation of transpositional cointegrates (see Methods). These can be resolved in the recipient by the cognate TnpR-res system, presuming that it is functional.

The data obtained (Table 4) show that despite efficient conjugal transfer of R906 and R772 $\left(\sim 4.0 \times 10^{-1}\right.$ per donor; see footnote), only the R772 ${ }^{+}$donor, and not that with R906, elicited transfer of pBR322 (lines 1 and 3). The R772-mediated events were attributed to Tn5403, since none occurred in the corresponding experiment involving R772-1, a $\operatorname{tnp} A_{5403}$ mutant (line 4). Confirmation of $\mathrm{Tn} 5403$ transposition was obtained by analysing four $\mathrm{Tc}^{\mathrm{R}}$ transconjugants (see Methods). All contained resolved pBR322::Tn5403 plasmids in which the insert was at a different site. In one of these (from a $\mathrm{Tc}^{\mathrm{R}} \mathrm{Ap}^{\mathrm{S}}$ transconjugant), Tn5403 was in amp of pBR322 (at nucleotide 4181), where it was flanked by 5 bp DRs (CATTT) and was able to relocate to pUB307 when tested further (data not shown). We concluded that Tn5403 of Tn511 is self-mobile and that its transposition to random target sites involves the formation of a cointegrate, a feature previously attributed to this element (Hille et al., 1983; Rinkel et al., 1994a). The failure of R906 to similarly transfer pBR322 (line 1) demonstrated that IS1071 of Tn510 is not selfmobile in this assay system, despite its reported ability to form transpositional cointegrates (Sota et al., 2006; Wyndham et al., 1994), and neither is Tn510 itself.
Line 2 of Table 4 shows that $\operatorname{tnp} A_{21}$ facilitated transfer of pBR322 by R906, presumably by restoring transposition of Tn510. This conclusion was confirmed by analysing four $\mathrm{Tc}^{\mathrm{R}} \mathrm{Ap}^{\mathrm{S}}$ transconjugants, three of which contained resolved pBR322amp: : Tn510 plasmids whose Tn510 insertion sites and orientation in $a m p$ were determined (i.e. at nucleotides 3710 and 4062 in $\beta$-orientation, at nucleotide 3530 in $\alpha$-orientation). The fourth plasmid (pVS1650) was an unusual R906-pBR322 cointegrate that had formed by Tn510 insertion into amp, but had not resolved because most of the second copy of Tn510 was absent (see Methods) (Fig. 3). The structural features of pVS1650 are interesting, as the pBR322 replicon is fortuitously enclosed by IRm1 and IRt1 termini, forming the novel pBR322Tn510 transposon Tn510-2 (Fig. 3). Although not formally tested, Tn510-2, like Tn510, should be capable of $\operatorname{tnp} A_{21^{-}}$ assisted transposition. The IRm1 and IRt1 termini of Tn510 were identified in all four plasmids studied and in each case they were flanked by different 5 bp DRs, consistent with transposition of a $\operatorname{Tn} 21 / \operatorname{Tn} 501$-like element.

We also studied $t n p A_{21}$-assisted transposition of $\operatorname{Tn} 511$ by using the Tn5403-inactive plasmid R772-1. Transposition was detected (line 5), and the resulting products in $19 \mathrm{Tc}^{\mathrm{R}}$ transconjugants were analysed further. All had recoverable pBR322::Tn plasmids that contained different parts of Tn511. Those from $10 \mathrm{Tc}^{\mathrm{R}} \mathrm{Km}^{\mathrm{S}}$ transconjugants were resolved pBR322:: Tn511-3 plasmids. All were of similar size $(\sim 12.5 \mathrm{~kb})$ and sequence analysis of four confirmed the presence of Tn511-3 (i.e. at nucleotides 2431, 2510 
and 3162 in $\alpha$-orientation, and at nucleotide 3143 in $\beta$-orientation). In each instance, the Tn511-3 insert was bounded by IRt 3 and IRm1, and flanked by 5 bp DRs. Larger plasmids $(\sim 22.5 \mathrm{~kb})$ were recovered from all nine $\mathrm{Tc}^{\mathrm{R}} \mathrm{Km}^{\mathrm{R}}$ transconjugants. One was identified as a pBR322:: Tn511 plasmid and eight as pBR322:: Tn511-2 plasmids, based on the presence or absence of the NcoI site located near IRt1 (Fig. 1). The latter group was further divisible into four (via HindIII profile), suggesting differences in either the position or the orientation of the inserted Tn511-2.

These various observations provide experimental evidence of bona fide transposition of Tn510 and Tn511, and of their components (Tn511-2, Tn511-3 and Tn5403), from their in situ locations in R906 or R772. With the exception of Tn5403, transposition of these otherwise immobile elements was assisted by $\operatorname{tnp} A_{21}$ supplied in trans. This feature is expected to extend to Tn510-2, a novel transposon that contains the pBR322 replicon. Our failure to detect transposition of IS1071 is consistent with a recent study (Sota et al., 2006) which showed that transposition is host-dependent and does not occur in E. coli as previously suspected.

\section{The aphAl region of $\mathrm{Tn} 511$ is inherently unstable}

The DNA sequence of Tn 511 revealed that aphAI is flanked by similarly oriented regions of homology of $>2 \mathrm{~kb}$ in length (i.e. $\operatorname{tnp} A 2$ and $\operatorname{tnp} A 3^{*}$ ) (Fig. 1). These regions are potential substrates for the host recombination (RecA) system, and could result in deletion of the intervening $\sim 10 \mathrm{~kb}$ region containing Tn5403, socD and aphAI. To test this possibility, PCRs were performed using primers SP32 and SP33 (Fig. 1) and template DNA from $\mathrm{Rec}^{+}$and $\mathrm{Rec}^{-}$ strains that had been grown for $\sim 25$ generations in the absence of kanamycin. The strains carried either R772 or pBR322:: Tn511 (pVS1719). PCR products were obtained only from the $\mathrm{Rec}^{+}$sources and were of $\sim 2.5 \mathrm{~kb}$ in size (Fig. 4), consistent with the presence of RecA-generated plasmid deletants involving ' $\operatorname{tn} p A 2$ and $\operatorname{tnp} A 3^{*}$. The greater product yield from the pBR322::Tn511 sample was attributed to the increased chance of deletions due to the smaller size and high copy number of this plasmid compared with R772. Indeed, $\sim 30 \%$ of the colonies grown from the $\operatorname{Rec}^{+}$pBR322::Tn $511^{+}$culture were $\mathrm{Km}^{\mathrm{S}}$, whereas no segregants were detected $(<1 \%)$ from the $\mathrm{Rec}^{+} \mathrm{R} 772^{+}$ culture. The extracted plasmids from four $\mathrm{Km}^{\mathrm{s}}$ segregants were all smaller $(\sim 10 \mathrm{~kb})$ than pBR322::Tn511 and differed from it in HindIII and EcoRI profiles, consistent with loss of the Tn5403-socD-aphAI segment (Fig. 1). These observations demonstrate the emergence of another new element from Tn511, denoted Tn511-4 (Fig. 1), that, like Tn511-3, has no associated phenotype. They also imply that the maintenance of R772 in its clinical strain (Coetzee, 1978), and since then in laboratory strains, was due to aminoglycoside selection pressure. Indeed, the latter may be a strict requirement, since expression of aphAI imposes a cost burden on its bacterial host (Kim et al., 2006).

\section{Hypothetical genesis of Tn510 and Tn511 and their evolutionary potential}

The DNA sequences of Tn510 (from R906) and Tn511 (from R772) and the experimental features of these elements provide clues to their origins. A simple scenario is that Tn510 and Tn511 evolved mainly by sequential acquisition of TEs and accompanying DNA rearrangements. In the primary event, $\mathrm{Tn} A O 22$ inserted into the Inc $\mathrm{P}$ oriV-trfA region, forming the extant $5 \mathrm{bp}$ target duplication. Other TEs were then acquired, altering TnAO22 internally and establishing the Tn510 and Tn511 lineages (Fig. 2). A derivative of Tn510 occurs in $\mathrm{pB} 10(\operatorname{IncP} \beta)$ (Schlüter et al., 2003). Its sequence and location are identical to those of Tn510, except that IS1071 is disrupted by a Tn1721-like element. A third lineage is represented by the element in pJP4 (Schlüter et al., 2003; Trefault et al., 2004): it retains the mer-IRm1 end of TnAO22 but the IRt end and adjacent backbone sequences have been replaced by the acquired TEs. An alternative scenario is that $\mathrm{Tn} A O 22$ evolved prior to its transposition into the same oriV-trfA site by a tnpA-assisted process (Table 4). This scenario is unlikely, since target specificity is not a feature of $\operatorname{Tn} 21 / \operatorname{Tn} 501$-like elements related to TnAO22 (Grinsted et al., 1990), although they favour the IncP $\beta$ ori $V-$ trfA region (Sota et al., 2007).

The various components of $\operatorname{Tn} 510$ and $\operatorname{Tn} 511$, except for the regions flanking socD and $a p h A I$, are recognizable genes or remnant TEs. We speculate that all may have been

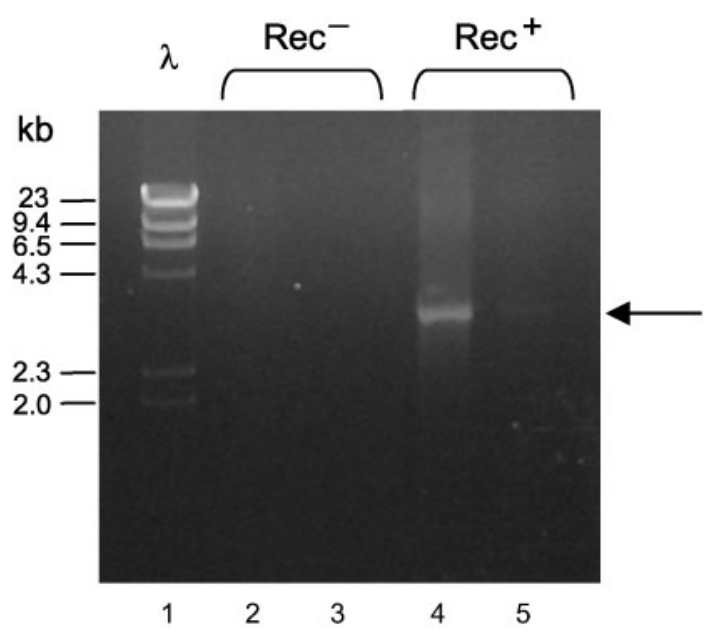

Fig. 4. Instability of the Tn5403-socD-aphA/ region of Tn511 in E. coli. Plasmid DNA isolated from RecA ${ }^{+}$(UB281) and RecA (UB5201) strains carrying either pBR322::Tn511 (pVS1719) or R772 was PCR-amplified using primers SP32 and SP33, and the reaction products were separated by electrophoresis on an agarose gel. Lanes: 1, $\lambda$ Hindlll-digested marker DNA; 2, pVS1719 ${ }^{+}$strain; 3, R772 ${ }^{+}$strain; 4, pVS1719 ${ }^{+}$strain; 5, $\mathrm{R}_{72}{ }^{+}$strain. The arrow indicates the position of a faint band that occurs in lane 5 . 
acquired from environmental bacteria given the ecology of the components. TnAO22 was detected in an Achromobacter sp. (Ng et al., 2009); however, the broader family of Tn21/Tn501-like elements is common in Gram-negative bacteria (Grinsted et al., 1990; Liebert et al., 1999; Yurieva et al., 1997). Tn5393 is typically associated with phytopathogens [e.g. Erwinia and Pseudomonas species (Chiou \& Jones, 1993; Sundin et al., 1995)], and IS1071 with pollutant-degrading bacteria [e.g. Comamonas and Pseudomonas species (Di Gioia et al., 1998; Wyndham et al., 1994)], including those that support IS 1071 transposition (Sota et al., 2006). Tn5403 was detected in aquatic enterobacteria [i.e. Klebsiella spp. and Enterobacter agglomerans (Rinkel et al., 1994a, b)], and socD genes occur in members of the Rhizobiaceae (Baek et al., 2005). The aphAI gene may have been from bacteria associated with humans or animals (Vakulenko \& Mobashery, 2003), and is possibly a TE remnant. Alternatively, the Tn511 aphAI-socD region may have been inherited en bloc by an unknown capture process. An agrobacterial/rhizobial source is possible, since kanamycin resistance occurs amongst these bacteria (Brockman \& Bezdicek, 1989; Cole \& Elkan, 1979; F. Taner \& V. A. Stanisich, unpublished data).

All of the above-mentioned bacteria could have been accessed by the ancestral IncP $\beta$ plasmid, since the IncP family in general has a broad host range (Sen et al., 2010; Thomas \& Smith, 1987) and occurs in diverse habitats (Bahl et al., 2009; Smalla et al., 2000). Tn510 and Tn511 have added interest, since R906 and R772 were isolated in the 1970s from vertebrate sources, yet their components, apart from Tn5403 and $\operatorname{soc} D_{511}$, are similar to those in environmentally sourced IncP plasmids. Some of the components (e.g. Tn5393 and Tn5403) appear to be disseminating more widely and have been found in complexes with other TEs or resistance genes in bacteria from humans (Boyd et al., 2004; L'Abée-Lund \& Sørum, 2000; Mantengoli \& Rossolini, 2005; Ruppé et al., 2009). The compositions of Tn510 and Tn511 thus lend support to the opinion that gene flow from environmental microcosms can affect bacteria present in humans (the source of R772) and animals (the source of R906) (Davies, 1994; Mindlin et al., 2006; Schlüter et al., 2007).

The genesis models (Fig. 2) also posit that the various components were acquired at different times, possibly as intact TEs, and were subject to mutational change. A missense mutation in $\operatorname{mer}_{511}$ (Table 3) accounts for the $\mathrm{Hg}^{\text {II }}$ sensitivity of R772, despite its full-length mer module. Deletion mutations caused either by the TEs or by homology (RecA)-dependent processes are also evident. TE-mediated events are expected to leave the TE intact, whilst removing the DR and adjoining DNA on one flank (Petrovski \& Stanisich, 2010; Wang et al., 1994). This type of event explains why Tn5403 and IS1071 each border a remnant gene and lack recognizable DRs, even though these are reinstated on subsequent transposition, as observed for Tn5403 (Table 4). Presumably, both elements could continue to initiate deletions, producing new variants. RecA-dependent deletions were not recognizable in Tn510 and Tn511; however, such events involving the $\operatorname{Tn} 511^{\prime} \operatorname{tn} p A 2$ and $\operatorname{tn} p A 3^{*}$ sequences account for the kanamycin-sensitive derivative Tn511-4 (Figs 1 and 4). A similar process in the Tn 510 derivative of $\mathrm{pB} 10$ could result in tetracycline-sensitive segregants.

To this point we have focused on the evolution of $\operatorname{Tn} 510$ and $\operatorname{Tn} 511$ in their $\operatorname{IncP} \beta$ carrier. Other evolutionary consequences attended transposition of the elements when assisted in trans by $\operatorname{tn} p A$ of $\operatorname{Tn} 21$. The $\operatorname{TnpA}_{21}$ transposase is relatively non-specific (Grinsted et al., 1990) and was able to recognize IRt1 and IRm1, which differ from the Tn21 termini, as well as the internal IRt2 and IRt3, which do not (Fig. 2a). Consequently, transposition of Tn510 and Tn511 was detected, and also that of Tn511-2 and Tn511-3 (Fig. 1, Table 4). Similar events enabling defective elements to escape from their carrier replicon could presumably occur during natural encounters of IncP plasmids and Tn21/Tn501-like transposons in the diverse habitats in which both occur (Smalla et al., 2000). One of the Tn510 transposition events resulted in the formation of an R906pBR322 cointegrate that was stabilized by the absence of a complete second copy of Tn510 (Table 4, Fig. 3). A similar stable cointegrate was formed between R772 and pTi in Agrobacterium, involving Tn5403 as the initiating element (Hille et al., 1983). Such cointegrates are presumably due to errors in the transposition process and may be relatively common. They enable the transfer of 'host-limited' genes (e.g. pBR322) to the pantheon of IncP hosts, where they may remain linked to the IncP replicon or have opportunities to separate from it, as predicted for the hybrid transposon Tn510-2 (Fig. 3).

In overview, this study of $\operatorname{Tn} 510$ and $\operatorname{Tn} 511$ shows how complex embedded structures may have arisen. We focused on the functional attributes of these elements to show that they are not genetic dead-ends but can contribute to horizontal gene transfer in perhaps unanticipated ways. Similar elements, varying in structural complexity, occur in other IncP plasmids (e.g. Tn4321 of R751; Partridge \& Hall, 2003; Thorsted et al., 1998) and indeed beyond the IncP family [e.g. the transposons in pWW53 (IncP-7); Yano et al., 2007]. Their occurrence reinforces the importance of accessory genes in plasmid diversity and, via the potentially advantageous encoded properties, to nichebased adaptation of the bacterial host.

\section{ACKNOWLEDGEMENTS}

We thank Ruth M. Hall, The University of Sydney, for providing us with plasmid pUB2401. S.P. was the recipient of a La Trobe University Postgraduate Award.

\section{REFERENCES}

Adamczyk, M. \& Jagura-Burdzy, G. (2003). Spread and survival of promiscuous IncP-1 plasmids. Acta Biochim Pol 50, 425-453. 
Baek, C.-H., Farrand, S. K., Park, D.-K., Lee, K. E., Hwang, W. \& Kim, K.-S. (2005). Genes for utilization of deoxyfructosyl glutamine (DFG), an amadori compound, are widely dispersed in the family Rhizobiaceae. FEMS Microbiol Ecol 53, 221-233.

Bahl, M. I., Burmølle, M., Meisner, A., Hansen, L. H. \& Sørensen, S. J. (2009). All IncP-1 plasmid subgroups, including the novel $\varepsilon$ subgroup, are prevalent in the influent of a Danish wastewater treatment plant. Plasmid 62, 134-139.

Barkay, T., Miller, S. M. \& Summers, A. O. (2003). Bacterial mercury resistance from atoms to ecosystems. FEMS Microbiol Rev 27, 355384.

Bennett, P. M., Grinsted, J. \& Richmond, M. H. (1977). Transposition of TnA does not generate deletions. Mol Gen Genet 154, 205-211.

Bolivar, F., Rodriguez, R. L., Greene, P. J., Betlach, M. C., Heyneker, H. L., Boyer, H. W., Crosa, J. H. \& Falkow, S. (1977). Construction and characterization of new cloning vehicles. II. A multipurpose cloning system. Gene 2, 95-113.

Boyd, D. A., Tyler, S., Christianson, S., McGeer, A., Muller, M. P., Willey, B. M., Bryce, E., Gardam, M., Nordmann, P., Mulvey, M. R. \& Canadian Nosocomial Infection Surveillance Program, Health Canada (2004). Complete nucleotide sequence of a 92-kilobase plasmid harboring the CTX-M-15 extended-spectrum beta-lactamase involved in an outbreak in long-term-care facilities in Toronto, Canada. Antimicrob Agents Chemother 48, 3758-3764.

Brockman, F. J. \& Bezdicek, D. F. (1989). Diversity within serogroups of Rhizobium leguminosarum biovar viceae in the Palouse region of Eastern Washington as indicated by plasmid profiles, intrinsic antibiotic resistance, and topography. Appl Environ Microbiol 55, 109-115.

Chiou, C.-S. \& Jones, A. L. (1993). Nucleotide sequence analysis of a transposon (Tn5393) carrying streptomycin resistance genes in Erwinia amylovora and other Gram-negative bacteria. J Bacteriol 175, 732-740.

Coetzee, J. N. (1978). Mobilization of the Proteus mirabilis chromosome by R plasmid R772. J Gen Microbiol 108, 103-109.

Cole, M. A. \& Elkan, G. H. (1979). Multiple antibiotic resistance in Rhizobium japonicum. Appl Environ Microbiol 37, 867-870.

Davies, J. (1994). Inactivation of antibiotics and the dissemination of resistance genes. Science 264, 375-382.

De Gelder, L. F., Vandecasteele, F. P., Brown, C. J., Forney, L. J. \& Top, E. M. (2005). Plasmid donor affects host range of promiscuous IncP- $1 \beta$ plasmid $\mathrm{pB} 10$ in an activated-sludge microbial community. Appl Environ Microbiol 71, 5309-5317.

De Gelder, L., Ponciano, J. M., Joyce, P. \& Top, E. M. (2007). Stability of a promiscuous plasmid in different hosts: no guarantee for a longterm relationship. Microbiology 153, 452-463.

de la Cruz, F. \& Grinsted, J. (1982). Genetic and molecular characterization of $\mathrm{Tn} 21$, a multiple resistance transposon from R100.1. J Bacteriol 151, 222-228.

Di Gioia, D., Peel, M., Fava, F. \& Wyndham, R. C. (1998). Structures of homologous composite transposons carrying $c b a A B C$ genes from Europe and North America. Appl Environ Microbiol 64, 1940-1946.

Grinsted, J., de la Cruz, F. \& Schmitt, R. (1990). The Tn21 subgroup of bacterial transposable elements. Plasmid 24, 163-189.

Hamlett, N. V., Landale, E. C., Davis, B. H. \& Summers, A. O. (1992). Roles of the $\operatorname{Tn} 21$ merT, merP, and merC gene products in mercury resistance and mercury binding. J Bacteriol 174, 6377-6385.

Hanahan, D. (1983). Studies on transformation of Escherichia coli with plasmids. J Mol Biol 166, 557-580.

Hedges, R. W., Datta, N., Coetzee, J. N. \& Dennison, S. (1973). $\mathrm{R}$ factors from Proteus morganii. J Gen Microbiol 77, 249-259.
Hedges, R. W., Jacob, A. E. \& Smith, J. T. (1974). Properties of an R factor from Bordetella bronchiseptica. J Gen Microbiol 84, 199204.

Hille, J., van Kan, J., Klasen, I. \& Schilperoort, R. (1983). Site-directed mutagenesis in Escherichia coli of a stable R772: Ti cointegrate plasmid from Agrobacterium tumefaciens. J Bacteriol 154, 693-701.

Hobman, J. L. \& Brown, N. L. (1996). Overexpression of MerT, the mercuric ion transport protein of transposon Tn501, and genetic selection of mercury hypersensitivity mutations. Mol Gen Genet 250, 129-134.

Kamachi, K., Sota, M., Tamai, Y., Nagata, N., Konda, T., Inoue, T., Top, E. M. \& Arakawa, Y. (2006). Plasmid pBP136 from Bordetella pertussis represents an ancestral form of IncP-1 $\beta$ plasmids without accessory mobile elements. Microbiology 152, 3477-3484.

Kamali-Moghaddam, M. \& Sundström, L. (2000). Transposon targeting determined by resolvase. FEMS Microbiol Lett 186, 55-59.

Kim, C., Cha, J. Y., Yan, H., Vakulenko, S. B. \& Mobashery, S. (2006). Hydrolysis of ATP by aminoglycoside $3^{\prime}$-phosphotransferases: an unexpected cost to bacteria for harboring an antibiotic resistance enzyme. J Biol Chem 281, 6964-6969.

Kovach, M. E., Elzer, P. H., Hill, D. S., Robertson, G. T., Farris, M. A., Roop, R. M., II \& Peterson, K. M. (1995). Four new derivatives of the broad-host-range cloning vector pBBR1MCS, carrying different antibiotic-resistance cassettes. Gene 166, 175-176.

Krishnapillai, V. (1988). Molecular genetic analysis of bacterial plasmid promiscuity. FEMS Microbiol Rev 4, 223-237.

Kung, V. L., Ozer, E. A. \& Hauser, A. R. (2010). The accessory genome of Pseudomonas aeruginosa. Microbiol Mol Biol Rev 74, 621-641.

L’Abée-Lund, T. M. \& Sørum, H. (2000). Functional Tn5393-like transposon in the $\mathrm{R}$ plasmid pRAS2 from the fish pathogen Aeromonas salmonicida subspecies salmonicida isolated in Norway. Appl Environ Microbiol 66, 5533-5535.

Liebert, C. A., Wireman, J., Smith, T. \& Summers, A. O. (1997). Phylogeny of mercury resistance (mer) operons of Gram-negative bacteria isolated from the fecal flora of primates. Appl Environ Microbiol 63, 1066-1076.

Liebert, C. A., Hall, R. M. \& Summers, A. O. (1999). Transposon Tn21, flagship of the floating genome. Microbiol Mol Biol Rev 63, 507522.

Lund, P. A. \& Brown, N. L. (1987). Role of the merT and merP gene products of transposon Tn501 in the induction and expression of resistance to mercuric ions. Gene 52, 207-214.

Ma, Y.-F., Wu, J.-F., Wang, S.-Y., Jiang, C.-Y., Zhang, Y., Qi, S.-W., Liu, L., Zhao, G.-P. \& Liu, S.-J. (2007). Nucleotide sequence of plasmid pCNB1 from Comamonas strain CNB-1 reveals novel genetic organization and evolution for 4-chloronitrobenzene degradation. Appl Environ Microbiol 73, 4477-4483.

Mantengoli, E. \& Rossolini, G. M. (2005). Tn5393d, a complex Tn5393 derivative carrying the PER-1 extended-spectrum $\beta$-lactamase gene and other resistance determinants. Antimicrob Agents Chemother 49, 3289-3296.

Minakhina, S., Kholodii, G., Mindlin, S., Yurieva, O. \& Nikiforov, V. (1999). Tn5053 family transposons are res site hunters sensing plasmidal res sites occupied by cognate resolvases. Mol Microbiol 33, 1059-1068.

Mindlin, S. Z., Petrova, M. A., Bass, I. A. \& Gorlenko, Zh. M. (2006). Origin, evolution, and migration of drug resistance genes. Russ $J$ Genet 42, 1257-1272.

Ng, S. P., Davis, B., Palombo, E. A. \& Bhave, M. (2009). A Tn5051-like mer-containing transposon identified in a heavy metal tolerant strain Achromobacter sp. AO22. BMC Res Notes 2, 38. 
Palombo, E. A., Yusoff, K., Stanisich, V. A., Krishnapillai, V. \& Willetts, N. S. (1989). Cloning and genetic analysis of tra cistrons of the Tra 2/Tra 3 region of plasmid RP1. Plasmid 22, 59-69.

Pansegrau, W., Lanka, E., Barth, P. T., Figurski, D. H., Guiney, D. G., Haas, D., Helinski, D. R., Schwab, H., Stanisich, V. A. \& Thomas, C. M. (1994). Complete nucleotide sequence of Birmingham IncP $\alpha$ plasmids. Compilation and comparative analysis. J Mol Biol 239, 623663.

Partridge, S. R. \& Hall, R. M. (2003). The IS 1111 family members IS4321 and IS5075 have subterminal inverted repeats and target the terminal inverted repeats of Tn21 family transposons. J Bacteriol $\mathbf{1 8 5}$, 6371-6384.

Petrovski, S. \& Stanisich, V. A. (2010). Tn502 and Tn512 are res site hunters that provide evidence of resolvase-independent transposition to random sites. J Bacteriol 192, 1865-1874.

Rinkel, M., Hubert, J.-C., Roux, B. \& Lett, M.-C. (1994a). Identification of a new transposon Tn5403 in a Klebsiella pneumoniae strain isolated from a polluted aquatic environment. Curr Microbiol 29, 249-254.

Rinkel, M., Hubert, J.-C., Roux, B. \& Lett, M.-C. (1994b). Transposon Tn5403, a mobilizable-helper element: complete nucleotide sequence and distribution in aquatic strains. FEMS Microbiol Ecol 15, 89-95.

Ruppé, E., Woerther, P.-L., Diop, A., Sene, A.-M., Da Costa, A., Arlet, G., Andremont, A. \& Rouveix, B. (2009). Carriage of CTX-M-15producing Escherichia coli isolates among children living in a remote village in Senegal. Antimicrob Agents Chemother 53, 3135-3137.

Sambrook, J., Fritsch, E. F. \& Maniatis, T. (1989). Molecular Cloning: a Laboratory Manual, 2nd edn. Cold Spring Harbor, NY: Cold Spring Harbor Laboratory.

Sanchez, J., Bennett, P. M. \& Richmond, M. H. (1982). Expression of elt-B, the gene encoding the B subunit of the heat-labile enterotoxin of Escherichia coli, when cloned in pACYC184. FEMS Microbiol Lett 14, 1-5.

Schlüter, A., Heuer, H., Szczepanowski, R., Forney, L. J., Thomas, C. M., Pühler, A. \& Top, E. M. (2003). The 64508 bp IncP-1 $\beta$ antibiotic multiresistance plasmid pB10 isolated from a waste-water treatment plant provides evidence for recombination between members of different branches of the IncP-1 $\beta$ group. Microbiology 149, 31393153.

Schlüter, A., Szczepanowski, R., Pühler, A. \& Top, E. M. (2007). Genomics of IncP-1 antibiotic resistance plasmids isolated from wastewater treatment plants provides evidence for a widely accessible drug resistance gene pool. FEMS Microbiol Rev 31, 449-477.

Sen, D., Yano, H., Suzuki, H., Król, J. E., Rogers, L., Brown, C. J. \& Top, E. M. (2010). Comparative genomics of pAKD4, the prototype IncP-1 $\delta$ plasmid with a complete backbone. Plasmid 63, 98-107.

Smalla, K., Krögerrecklenfort, E., Heuer, H., Dejonghe, W., Top, E., Osborn, M., Niewint, J., Tebbe, C., Barr, M. \& other authors (2000). PCR-based detection of mobile genetic elements in total community DNA. Microbiology 146, 1256-1257.

Smith, C. A. \& Thomas, C. M. (1987). Comparison of the organisation of the genomes of phenotypically diverse plasmids of incompatibility group P: members of the IncP $\beta$ sub-group are closely related. Mol Gen Genet 206, 419-427.

Smith, C. A. \& Thomas, C. M. (1989). Relationships and evolution of IncP plasmids. In Promiscuous Plasmids of Gram-Negative Bacteria, pp. 57-77. Edited by C. M. Thomas. London: Academic Press.
Smith, C. A., Pinkney, M., Guiney, D. G. \& Thomas, C. M. (1993). The ancestral IncP replication system consisted of contiguous oriV and $\operatorname{trf} A$ segments as deduced from a comparison of the nucleotide sequences of diverse IncP plasmids. J Gen Microbiol 139, 1761-1766.

Sota, M., Yano, H., Nagata, Y., Ohtsubo, Y., Genka, H., Anbutsu, H., Kawasaki, H. \& Tsuda, M. (2006). Functional analysis of unique class II insertion sequence IS1071. Appl Environ Microbiol 72, 291-297.

Sota, M., Tsuda, M., Yano, H., Suzuki, H., Forney, L. J. \& Top, E. M. (2007). Region-specific insertion of transposons in combination with selection for high plasmid transferability and stability accounts for the structural similarity of IncP-1 plasmids. J Bacteriol 189, 3091-3098.

Sundin, G. W., Monks, D. E. \& Bender, C. L. (1995). Distribution of the streptomycin-resistance transposon Tn5393 among phylloplane and soil bacteria from managed agricultural habitats. Can J Microbiol 41, 792-799.

Terakado, N. \& Mitsuhashi, S. (1974). Properties of R factors from Bordetella bronchiseptica. Antimicrob Agents Chemother 6, 836-840.

Thomas, C. M. (2000). The Horizontal Gene Pool - Bacterial Plasmids and Gene Spread. Amsterdam: Harwood Academic Publishers.

Thomas, C. M. \& Smith, C. A. (1987). Incompatibility group P plasmids: genetics, evolution, and use in genetic manipulation. Annu Rev Microbiol 41, 77-101.

Thorsted, P. B., Macartney, D. P., Akhtar, P., Haines, A. S., Ali, N., Davidson, P., Stafford, T., Pocklington, M. J., Pansegrau, W. \& other authors (1998). Complete sequence of the $\operatorname{IncP} \beta$ plasmid R751: implications for evolution and organisation of the IncP backbone. J Mol Biol 282, 969-990.

Trefault, N., De la Iglesia, R., Molina, A. M., Manzano, M., Ledger, T., Pérez-Pantoja, D., Sánchez, M. A., Stuardo, M. \& González, B. (2004). Genetic organization of the catabolic plasmid pJP4 from Ralstonia eutropha JMP134 (pJP4) reveals mechanisms of adaptation to chloroaromatic pollutants and evolution of specialized chloroaromatic degradation pathways. Environ Microbiol 6, 655-668.

Vakulenko, S. B. \& Mobashery, S. (2003). Versatility of aminoglycosides and prospects for their future. Clin Microbiol Rev 16, 430-450.

Villarroel, R., Hedges, R. W., Maenhaut, R., Leemans, J., Engler, G., Van Montagu, M. \& Schell, J. (1983). Heteroduplex analysis of Pplasmid evolution: the role of insertion and deletion of transposable elements. Mol Gen Genet 189, 390-399.

Wang, G., Xu, X., Chen, J. M., Berg, D. E. \& Berg, C. M. (1994). Inversions and deletions generated by a mini- $\gamma \delta(\operatorname{Tn} 1000)$ transposon. J Bacteriol 176, 1332-1338.

Wyndham, R. C., Cashore, A. E., Nakatsu, C. H. \& Peel, M. C. (1994). Catabolic transposons. Biodegradation 5, 323-342.

Yano, H., Garruto, C. E., Sota, M., Ohtsubo, Y., Nagata, Y., Zylstra, G. J., Williams, P. A. \& Tsuda, M. (2007). Complete sequence determination combined with analysis of transposition/site-specific recombination events to explain genetic organization of IncP-7 TOL plasmid pWW53 and related mobile genetic elements. J Mol Biol 369, 11-26.

Yurieva, O., Kholodii, G., Minakhin, L., Gorlenko, Z., Kalyaeva, E., Mindlin, S. \& Nikiforov, V. (1997). Intercontinental spread of promiscuous mercury-resistance transposons in environmental bacteria. Mol Microbiol 24, 321-329.

Edited by: E. M. Top 